\title{
GROUND-WATER-LEVEL FLUCTUATIONS IN WASATCH FRONT LANDSLIDES AND ADJACENT SLOPES, NORTHERN UTAH
}
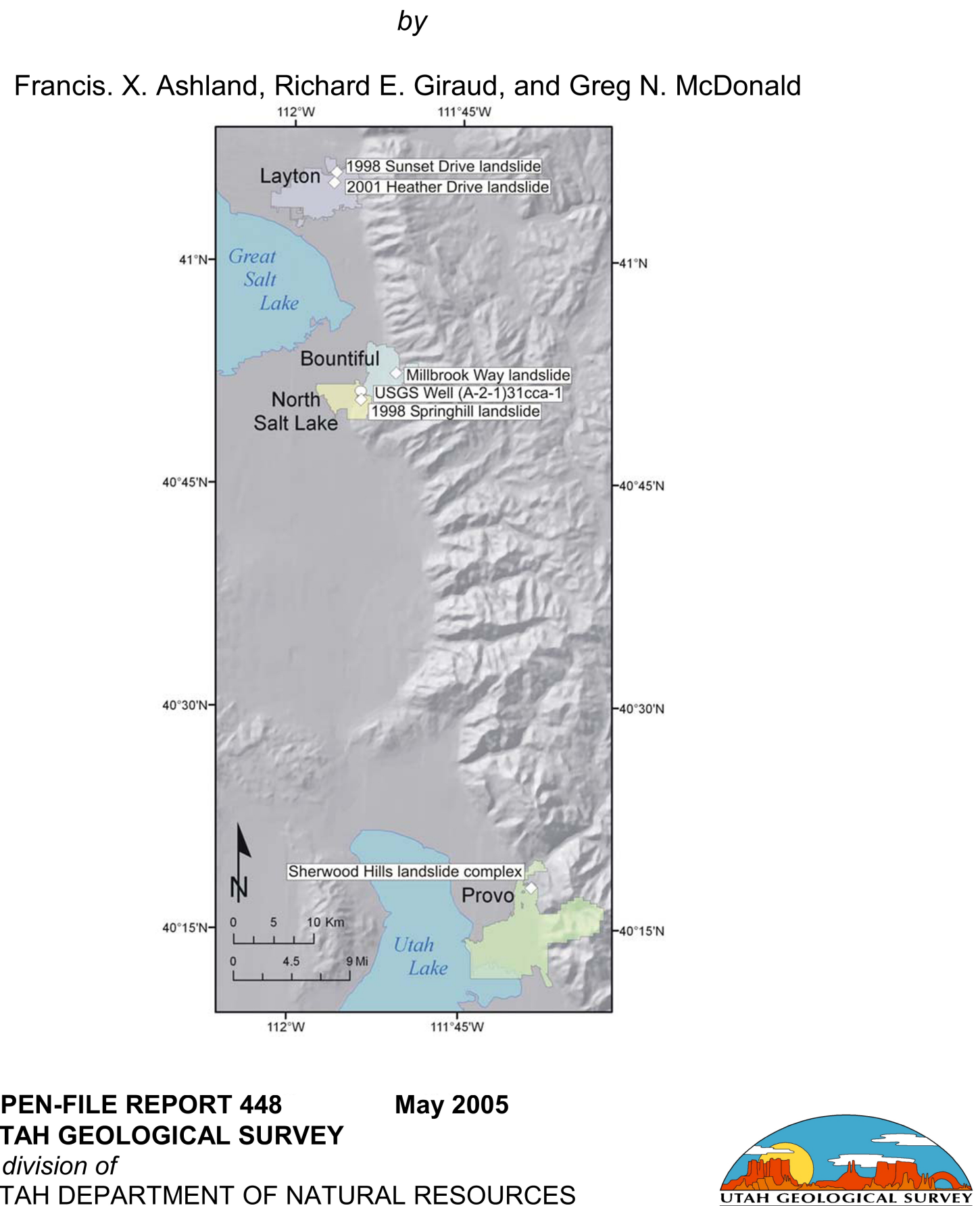

Although this product represents the work of professional scientists, the Utah Department of Natural Resources, Utah Geological Survey, makes no warranty, stated or implied, regarding its suitability for a particular use. The Utah Department of Natural Resources, Utah Geological Survey, shall not be liable under any circumstances for any direct, indirect, special, incidental, or consequential damages with respect to claims by users of this product. and editorial standards of the Utah Geological Survey. Thus it may be premature for an individual or group to take action based on its contents. 


\title{
GROUND-WATER-LEVEL FLUCTUATIONS \\ IN WASATCH FRONT LANDSLIDES \\ AND ADJACENT SLOPES, NORTHERN UTAH
}

\author{
by \\ Francis. X. Ashland \\ Richard E. Giraud \\ and \\ Greg N. McDonald
}

\begin{abstract}
Although this product represents the work of professional scientists, the Utah Department of Natural Resources, Utah Geological Survey, makes no warranty, express or implied, regarding its suitability for a particular use. The Utah Department of Natural Resources, Utah Geological Survey, shall not be liable under any circumstances for any direct, indirect, special, incidental, or consequential damages with respect to claims by users of this product.
\end{abstract}

This open-file release makes information available to the public in a timely manner. It may not conform to policy and editorial standards of the Utah Geological Survey. Thus it may be premature for an individual or group to take action based on its contents. 


\section{CONTENTS}

ABSTRACT ... -

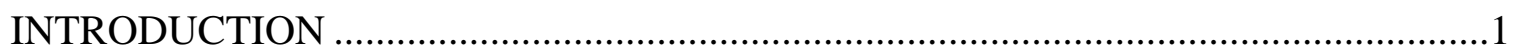

BACKGROUND …

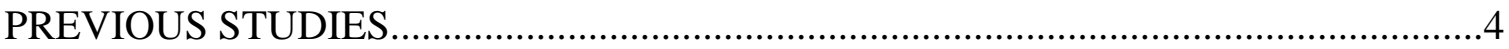

GROUND-WATER-LEVEL FLUCTUATIONS IN LANDSLIDES AND

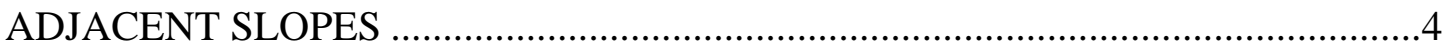

Long-Term Fluctuations in Unconsolidated Quaternary Deposits

near Historical Landslides................................................................................4

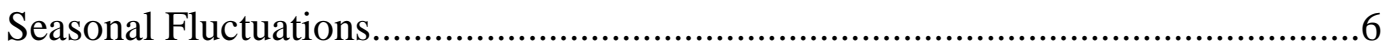

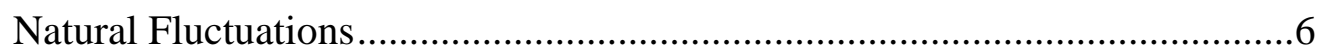

Fluctuations Induced by Landscape Irrigation................................................8

Timing of Seasonal Peak Levels ................................................................... 9

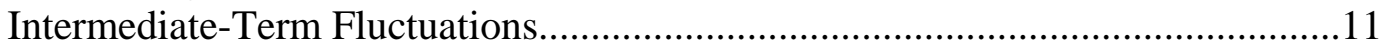

Magnitude of Seasonal and Intermediate-Term Fluctuations ...................................14

Sunset Drive Landslide, Layton...........................................................14

Springhill Landslide, North Salt Lake .....................................................15

Millbrook Way Landslide, Bountiful............................................................16

RELATION BETWEEN GROUND-WATER LEVELS AND PRECIPITATION ..........17

Monthly Precipitation ...................................................................................18

Annual Precipitation ………………................................................................18

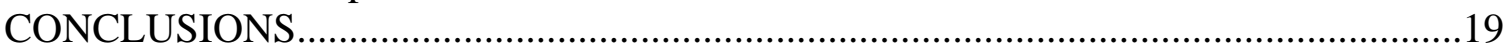

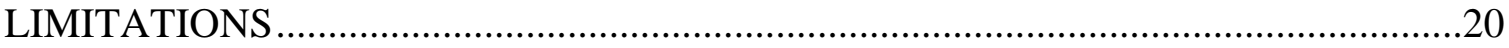

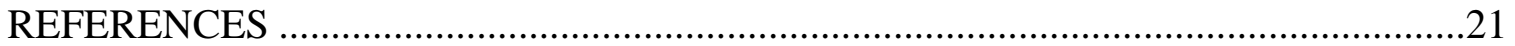

\section{FIGURES}

Figure 1. Location of historical landslides and well completed in unconsolidated

Quaternary deposits

Figure 2. Long-term ground-water-level rise since 1960 in unconsolidated Quaternary

deposits in southern Davis County ...........................................................................5

Figure 3. Detail of figure 1 showing rise in ground-water level during last two precipitation periods.

Figure 4. Natural seasonal fluctuation of the ground-water level in the lower part of the Sunset Drive landslide, Layton

Figure 5. Landscape-irrigation-induced fluctuation of the ground-water level in the crown of the Sunset Drive landslide, Layton

Figure 6. Histogram showing timing of natural peak seasonal ground-water levels in the lower part of the Sunset Drive landslide, Layton

Figure 7. Histogram showing timing of peak seasonal ground-water levels in the upper part of the Sunset Drive landslide, Layton

Figure 8. April ground-water level in the lower part of the Sunset Drive landslide, Layton 
Figure 9. April ground-water level in the crown of the Sunset Drive landslide,

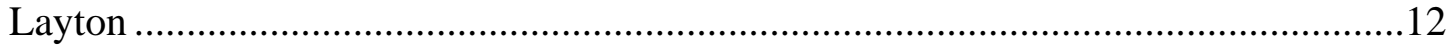

Figure 10. Decline in peak ground-water level in the upper part of the Springhill

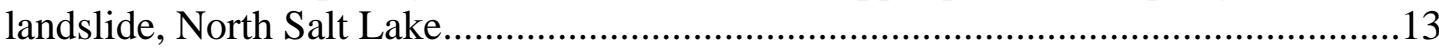

Figure 11. Decline in March ground-water level in the active part of the Sherwood Hills landslide complex, Provo.

Figure 12. Natural seasonal fluctuation in ground-water level in the head of the Millbrook Way landslide, Bountiful

Figure 13. Relation between ground-water level and monthly precipitation in the crown of the Sunset Drive landslide, Layton.

Figure 14. Relation between ground-water level and annual precipitation in the lower part of the Sunset Drive landslide, Layton

\section{TABLES}

Table 1. Summary of ground-water-level fluctuations in well B-3, Sunset Drive landslide, Layton

Table 2. Summary of natural seasonal and landscape-irrigation-induced ground-water-level fluctuations in well B-107, Sunset Drive landslide

Table 3. Seasonal and measured total fluctuations in ground-water levels, Sunset Drive landslide

Table 4. Seasonal and measured total fluctuations in ground-water levels, Springhill landslide, North Salt Lake.

Table 5. Seasonal fluctuations in ground-water levels, Millbrook Way landslide, Bountiful.... 


\begin{abstract}
We monitored ground-water levels in and adjacent to five Wasatch Front landslides to document seasonal and intermediate-term ground-water-level fluctuations that can be used to estimate design ground-water levels in landslide- and slope-stability analyses. Our data span a relative drought period (1999-2003), but locally document the effects of wetter than normal precipitation on ground-water levels in 2004.

Data by others show that ground-water levels in unconsolidated deposits near recently active landslides have risen tens of feet since the 1960s. Ground-water levels rose mostly during and immediately prior to a wet cycle that occurred between 1967 and 1998, but may be ongoing. During the wet cycle about 24 inches of cumulative excess precipitation occurred in Salt Lake City. The long-term rise in ground-water levels resulted in historically high levels in the late 1990s that coincided with active landsliding.

Our data show that seasonal ground-water levels fluctuate in response to both late winter/early spring snowmelt (natural seasonal fluctuation) and locally to summertime landscape irrigation (lawn watering) (irrigation-induced fluctuation). Seasonal groundwater levels during the measurement period fluctuated up to a maximum of 8.3 feet, with mean fluctuations ranging from about 0.7 to 6.6 feet at three of the landslides. Our data also indicate more variability in natural (seasonal) peak ground-water levels than in seasonal low levels in a single well. The timing of seasonal peak ground-water levels is an important consideration in estimating design ground-water levels as part of landslideand slope-stability evaluations.

Our data provide some preliminary insight into intermediate-term (spanning several years) fluctuations in ground-water levels in landslides, but more data are needed. The measured total fluctuation at the Sunset Drive (Layton) and Springhill (North Salt Lake) landslides ranged from 5.2 to 8.8 feet and from 3.1 to 4.5 feet, respectively. A decline in ground-water level of 14 feet occurred in a well in the upper part of the Sherwood Hills landslide complex, between 2000 and 2004. Measurements of same-month and/or peak levels showed that ground-water levels generally declined over the drought period (19992003), but locally rose in response to wetter than normal conditions in 2004. Preliminary data suggest the rebound in ground-water levels in wet periods is more rapid than the decline during dry periods.
\end{abstract}

\title{
INTRODUCTION
}

Limited data exist on ground-water levels and fluctuations in landslides and adjacent slopes in the Wasatch Front, despite the criticality of such information to accurate landslide- and slope-stability evaluation. Most ground-water-level data collected by consultants is limited to a short duration defined by the length of the project. Thus, a limited basis for estimating the probable short (seasonal) and long-term fluctuations in ground-water levels in and near landslides exists. 
The purpose of this study is to document ground-water-level fluctuations in specific, previously instrumented (with ground-water monitoring wells) landslides and adjacent slopes. This data is intended to provide geotechnical engineers a preliminary basis for estimating design ground-water levels in landslide- and slope-stability analyses. In the future, we intend to update this report as new data provide better information on longterm fluctuations in ground-water levels.

In this report, we compile and analyze ground-water-level data at five separate Wasatch Front landslides, and our results document both seasonal (within a single year) and intermediate-term (over a period of several years) fluctuations in levels. Our study spans a drought that began in 1999 and lasted through most of 2003, and our results document the impact on ground-water levels of successive dry years. We also document the rapid rise in seasonal high ground-water levels that occurred during the last year of this study (2004), which was locally wetter than normal. This report also includes information on the timing of peak ground-water levels, an important consideration in estimating design ground-water levels.

\section{BACKGROUND}

In 1999, the Utah Geological Survey began systematically measuring ground-water levels in monitoring wells installed as part of mostly publicly funded stability evaluations of damaging landslides conducted by consultants. Our measurements were typically made monthly or even less frequently and may not record the extreme seasonal high and low ground-water levels. We combined our measurements with previous ones in consultant reports. We used monitoring wells in five historical landslide areas along the Wasatch Front:

1. the Sunset Drive landslide, Layton,

2. the Heather Drive landslide, Layton,

3. the Millbrook Way landslide, Bountiful,

4. the Springhill landslide, North Salt Lake, and

5. the Sherwood Hills landslide complex, Provo.

Of these, only the upper part of the Sherwood Hills landslide complex remained active throughout most of the study period (1999-2004). Geologic materials in these landslides include fine-grained Lake Bonneville lacustrine deposits (Sunset Drive and Heather Drive landslides), lacustrine shoreline gravels (Millbrook Way landslide), weathered Tertiary volcanic rock (Springhill landslide), and weathered Paleozoic shale (Sherwood Hills landslide complex). All except the Springhill landslide are reactivations of preexisting landslides. Fill soils locally overlie native deposits at most of these slides (Sunset Drive, Heather Drive, and Sherwood Hills landslides). 


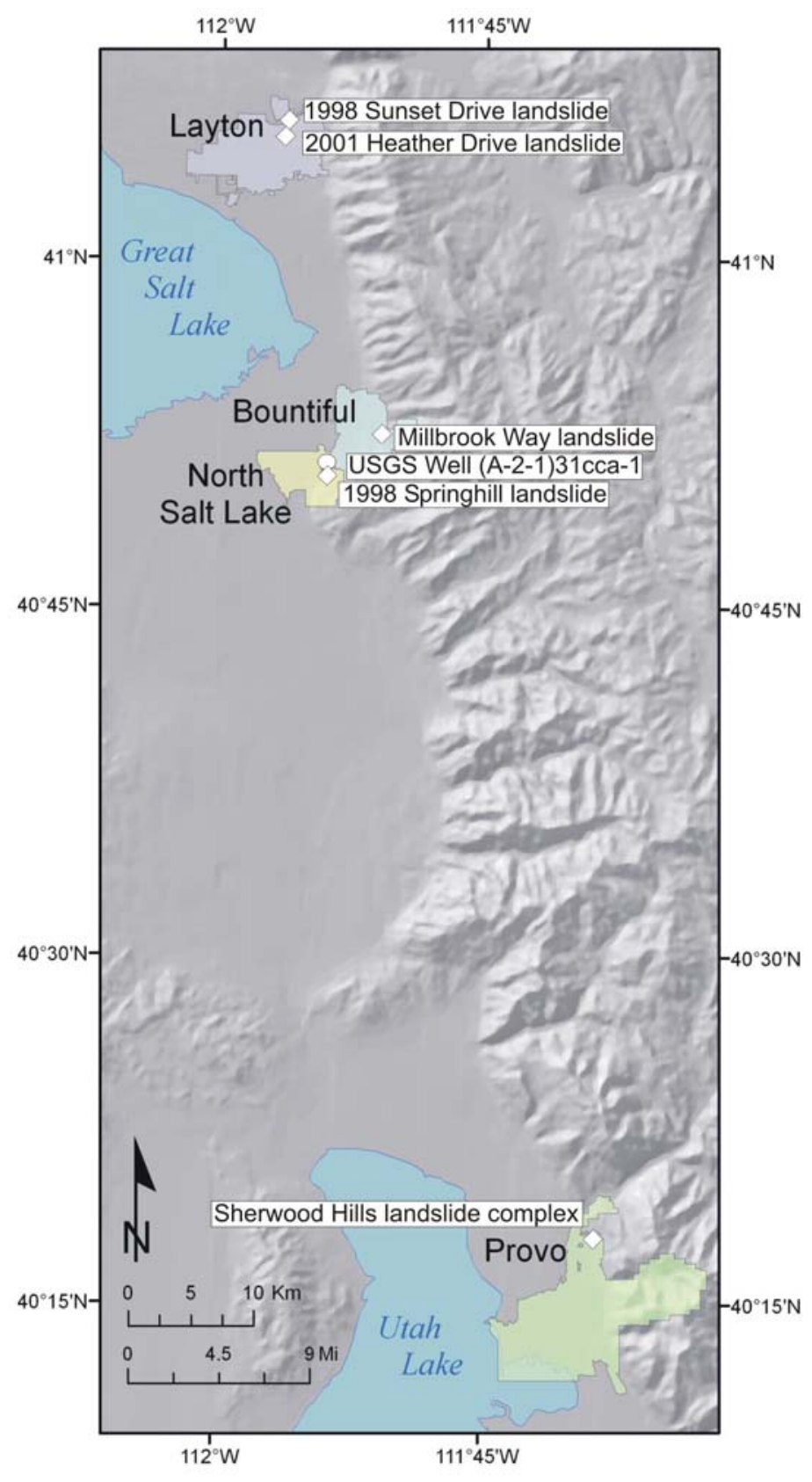

Figure 1. Location of historical landslides and wells completed in unconsolidated Quaternary deposits. 


\section{PREVIOUS STUDIES}

Kaliser and Slosson (1988) documented the rise in ground-water levels in Utah, affecting both confined and unconfined ground water, and the occurrence of perched ground water during the wet years of the early 1980s (1981-1984). Burden and others (2000) documented the rise in ground-water levels in some wells completed in unconsolidated Quaternary deposits in the Wasatch Front to historical high levels in the late 1990s. Ashland (2003) recognized that active landsliding in southern Davis and northern Salt Lake Counties in the late 1990s coincided with historically high groundwater levels in nearby wells. In addition, Ashland (2003) inferred that the rise in groundwater levels documented by Burden and others (2000) was caused, in part, by the infiltration of excess precipitation during a long-term wet cycle (Fleming and Schuster, 1985) that spanned the period between 1967 and 1998. Ashland (2003) also documented a landscape-irrigation-induced rise in ground-water levels at two Wasatch Front landslides and a transient rise in ground-water level due to an intense rainstorm event. Initial ground-water-level measurements at several of the landslides in this study were made as part of landslide-stability-evaluation studies performed by consultants (Terracon 1998a, 1998b, 1999, 2001, 2002; Terracon Consultants, Inc., 1998; URS/Dames \& Moore, 2001).

\section{GROUND-WATER-LEVEL FLUCTUATIONS IN LANDSLIDES AND ADJACENT SLOPES}

This study documents and analyzes ground-water-level data collected between late 1998 and 2004. Our data include ground-water levels compiled from other sources (Burden and others, 2002; Terracon 1998a, 1998b, 1999, 2000, 2001, 2004, 2004). The long-term ground-water levels documented by Burden and others (2000) provide the best estimate for the changes in ground-water levels in landslides prior to this study, despite that the measurements were not in wells completed in landslides. Our data document seasonal and intermediate-term fluctuations in ground-water levels that occurred mostly during a regional drought from 1998 and through 2003.

\section{Long-Term Fluctuations in Unconsolidated Quaternary Deposits near Historical Landslides}

Long-term ground-water-level data for Wasatch Front landslides is currently lacking, but our data provide some insight into long-term ground-water-level fluctuations in landslides. In addition, long-term ground-water-level fluctuations in landslides can be inferred from wells in nearby unconsolidated deposits. Figure 2 shows the long-term ground-water-level rise since 1960 in a well completed in lacustrine deposits in southern Davis County near the Springhill landslide that was active in 1998. The historical high ground-water level at this well occurred in 1999, a year after damaging movement of the Springhill landslide. The ground-water level in this well rose almost 22 feet between 1960 and 1999. About 8.5 feet of this rise occurred during a wet cycle (Fleming and 
Schuster, 1985) between 1967 and 1998 during which almost 24 inches of excess precipitation fell (Ashland, 2003). The wet cycle included three periods characterized by four or more successive wetter than normal years (1967-71, 1980-86, and 1995-98) referred to as precipitation periods (Ashland, 2003). The total rise in ground-water level during the three combined precipitation periods was about 10.5 feet; the 2-foot difference from the rise during the entire wet cycle is a result of declines in ground-water levels during intervening dry years (1972-79 and 1987-94). Most of this rise occurred during the last two precipitation periods (4.5 feet during the 1980-86 precipitation period and 4.7 feet during the 1995-98 precipitation period) that each contain one of the two wettest calendar years on record in Salt Lake City (1983 and 1998) (figure 3).

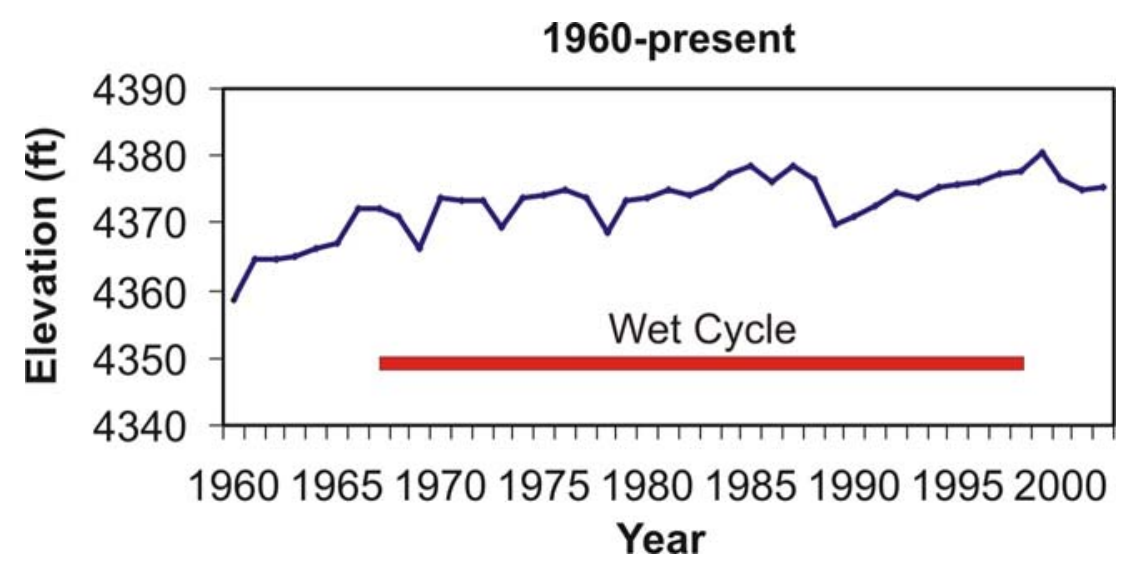

Figure 2. Long-term ground-water-level rise since 1960 in unconsolidated Quaternary (lacustrine) deposits in southern Davis County. USGS well (A-2-1)31cca-1 (Burden and others, 2000). March ground-water level shown. Bar shows time span of wet cycle of Fleming and Schuster (1985) as interpreted by Ashland (2003). 


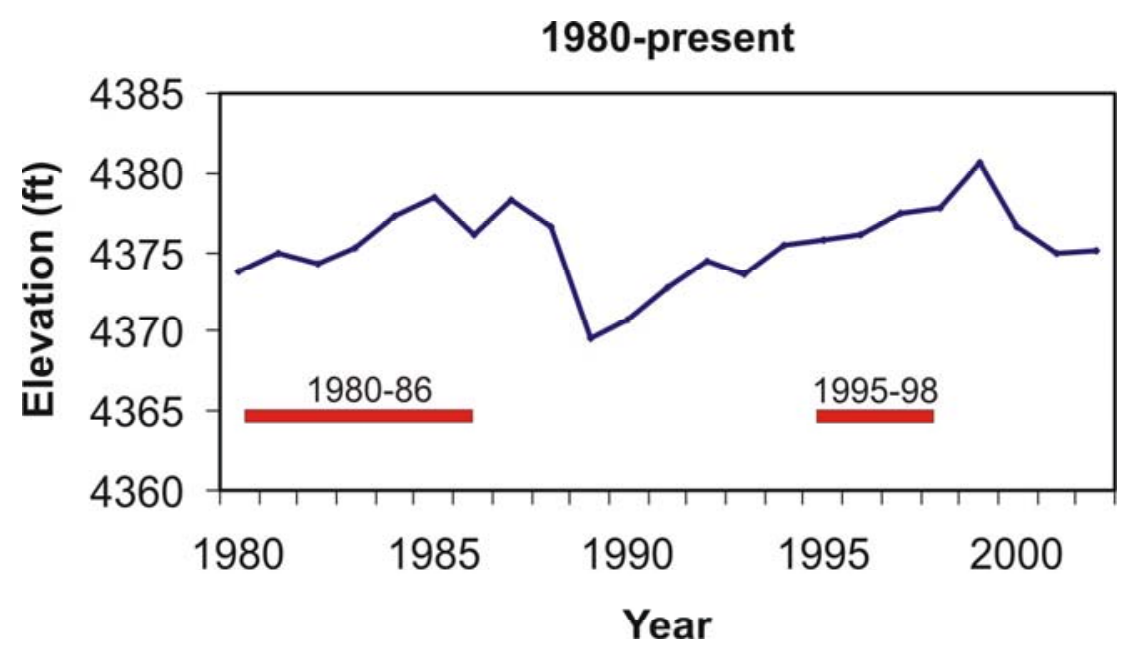

Figure 3. Detail of figure 1 showing rise in ground-water level during the last two precipitation periods (horizontal bars show time span of each). USGS well (A-21)31cca-1 (Burden and others, 2000). March ground-water level shown. Bars show time spans of the two most recent precipitation periods of Ashland (2003).

\section{Seasonal Fluctuations}

We identify two types of seasonal ground-water-level fluctuations: natural seasonal fluctuations controlled mostly by the late winter/early spring snowmelt recharge and seasonal fluctuations caused by infiltration of excess summer landscape irrigation water. The former is characterized by a single peak ground-water level that typically occurs before June, whereas the latter is characterized by a bimodal curve where the peak ground-water level occasionally occurs in the later summer or fall near the end of the landscape irrigation season.

\section{Natural Fluctuations}

Natural seasonal fluctuations of ground-water levels have been identified in several of the landslide areas in this study. At the Sunset Drive landslide, fluctuations in groundwater level in the lower, undeveloped part of the slide are controlled by the snowmelt in late winter/early spring (figure 4). Well B-3 in figure 4 is completed in the lower main body of the landslide. Ground-water-level fluctuations in well B-3 differ from those in wells farther upslope in the slide, so we believe the ground water in this well is hydraulically isolated from the shallow ground water in the upper part of the slide. Our interpretation of the borehole log for this well (Terracon Consultants, Inc., 1998) is that ground water is perched in a silty sand and silt layer overlying a lean clay layer. Since 1999, the peak seasonal ground-water level has occurred sometime between March and May coincident with the snowmelt and the three wettest months of the year (March through May in Salt Lake City), and the low seasonal ground-water level consistently occurred in either September or October following the dry summer months. 


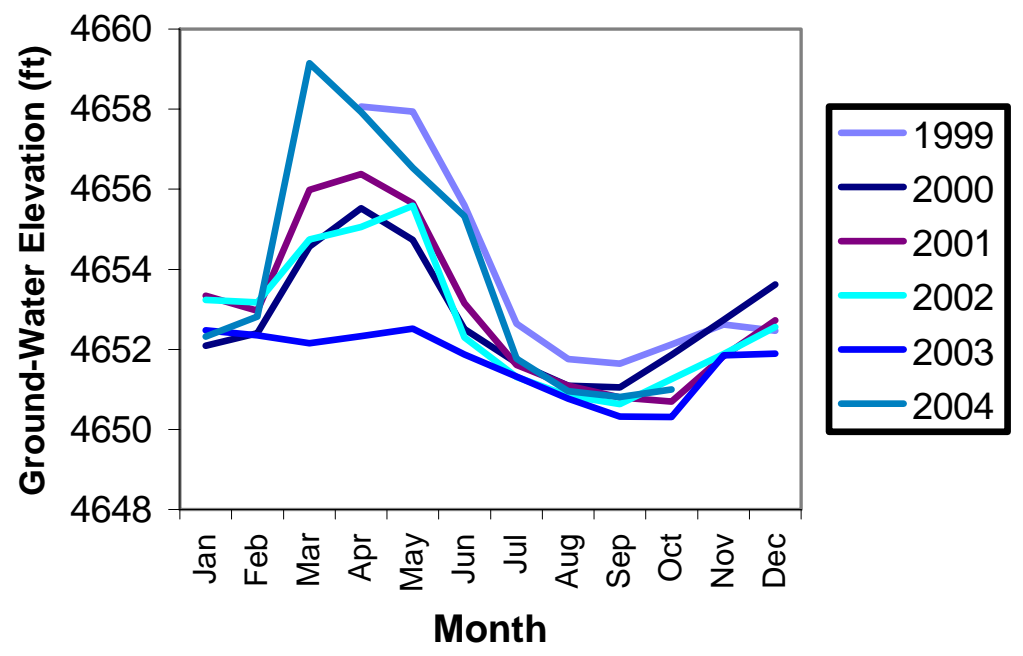

Figure 4. Natural seasonal fluctuation of the ground-water level in the lower part of the Sunset Drive landslide, Layton. Well B-3 (Terracon Consultants, Inc., 1998).

Figure 4 also shows different responses in the seasonal peak and low ground-water levels in well B-3 to varying precipitation conditions between 1999 and 2004. During this period, seasonal peak ground-water level varied by 6.6 feet, whereas the seasonal low level only varied by 1.3 feet. Seasonal peak ground-water level is primarily controlled by snowmelt recharge, and differences in late-winter, low-elevation snowpack are likely the primary cause of the variation. Seasonal low ground-water level in well B-3 is likely controlled by the ground-water gradient and the discharge conditions in the lower part of the landslide. Flowing springs and a seep in the lower landslide tend to dry up by late summer as ground-water levels decline, reducing the ability of further lowering of the ground-water level. Somewhat surprising is the limited variation in low seasonal level despite successive drier than normal conditions for most of the period (particularly from 2001 through 2003). We believe this supports our inference that the low seasonal ground-water level is primarily controlled by the ground-water gradient. In addition to the drying up of the springs and the seep in the lower slope, we infer that a diminishing capacity to lower ground-water levels accompanies a flattening of the gradient as groundwater levels decline in early summer in the upper part of the slope.

The importance of snowmelt recharge on the peak ground-water level is illustrated by the differences between the fluctuations in 2003 and 2004. In late winter 2003, a lowelevation snowpack was absent in the Wasatch Front, but present in late winter 2004. A snowpack measurement on the Sunset Drive landslide on February 5, 2004, indicated a snow-water content of 5.2 inches on the lower part of the slide, or about 32 percent of the normal annual precipitation in Salt Lake City. The lack of a low-elevation snowpack, and particularly the absence of snow cover on the Sunset Drive landslide, in 2003 resulted in a seasonal peak ground-water level only 1.9 feet above the preceding seasonal low level. In contrast, in 2004 the peak ground-water level was 8.8 feet above the seasonal low. Figure 3 shows that the steepest rise in ground-water level more often 
coincides with the snowmelt during February and March rather than with spring rainfall during the wet spring months of April and May. By May, ground-water levels are typically declining or have started to decline. Table 1 summarizes the seasonal and total measured fluctuations in ground-water level in well B-3.

Table 1. Summary of ground-water-level fluctuations in well B-3, Sunset Drive landslide, Layton.

\begin{tabular}{lc}
\hline Range in seasonal fluctuation (calendar year) & $2.2(2003)$ to $8.3(2004) \mathrm{ft}$ \\
Mean seasonal fluctuation & $5.4 \mathrm{ft}$ \\
\hline Maximum total measured fluctuation & $8.8 \mathrm{ft}$ \\
Maximum ground-water level & March 2004 \\
Minimum ground-water level & October 2003 \\
\hline
\end{tabular}

\section{Fluctuations Induced by Landscape Irrigation}

Landscape irrigation (lawn watering) in the Wasatch Front diverts a considerable amount of water into hillslopes and infiltration of excess lawn water recharges the shallow ground-water table. In some Salt Lake City residential areas, homeowners apply up to 200 inches of water to their lawns despite the need for only 30 inches a year to sustain a healthy lawn (Hayes, 2003). This amount of landscape irrigation water is equivalent to roughly 12 times the annual precipitation (16.18 inches) in Salt Lake City.

A summertime rise in the shallow, unconfined ground-water table has been identified in wells in the upper, developed parts of two Layton landslides: the Sunset Drive and Heather Drive landslides. At both landslides, fill soil exists in the upper part of the slide and crown area upslope of the main scarp. The main scarps of both landslides occur in residential areas where landscape irrigation (lawn watering) occurs upslope of the slides. Figure 4 shows the seasonal fluctuation in ground-water level of well B-107 completed in the crown of the Sunset Drive landslide. Well B-107 is completed in interlayered lean clay and sand in the crown of the landslide. The upper part of the borehole may be in clay fill, a result of hillslope grading prior to development, although fill is not identified in the borehole log of Terracon (1998b). A residential area surrounds the borehole.

With the exception of 2003, a year with no low-elevation snowpack, ground-waterlevel curves in figure 5 are bimodal. Since 1999, peak seasonal ground-water level varies between spring and late summer, occurring in the latter in four of six years of measurement. All four years were drier than normal which likely promoted excess landscape irrigation during the summer. The peak ground-water level coincided with the snowmelt recharge in only two years, 1999 and 2004. In both years, cumulative precipitation beginning September 1 (the informal landslide water year of Ashland, 2003) was near or above normal through most of the late winter and spring. Table 2 summarizes the seasonal, irrigation-induced, and total measured fluctuations in groundwater level for well B-107. 


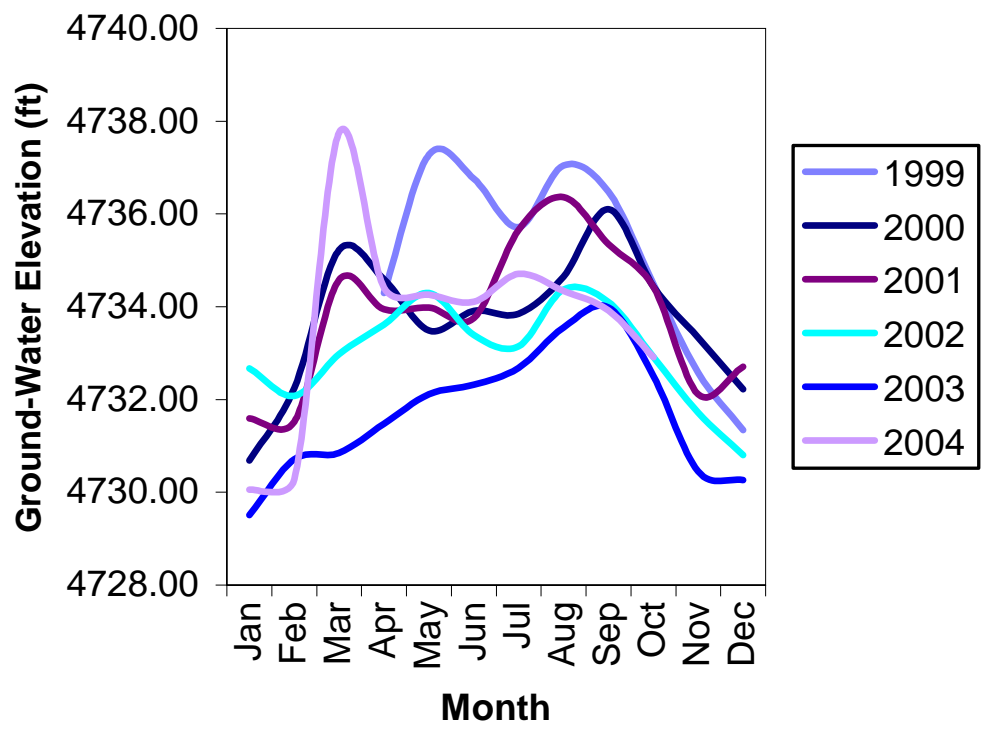

Figure 5. Landscape-irrigation-induced fluctuation of the ground-water level in the crown of the Sunset Drive landslide, Layton. Ground-water-level curves are bimodal except in 2003. The first ground-water-level peak coincident with snowmelt recharge occurs in March through May and a later irrigation-induced peak occurs in August and September. Well B-107 (Terracon, 1998b).

Table 2. Summary of natural seasonal and landscape irrigation-induced ground-water fluctuations in well B-107, Sunset Drive landslide, Layton.

\begin{tabular}{lc}
\hline Range in seasonal fluctuation (calendar year) & $3.6(2002)$ to $7.7(2004) \mathrm{ft}$ \\
Mean seasonal fluctuation & $5.3 \mathrm{ft}$ \\
\hline Range in irrigation-induced fluctuation (calendar year) & $3.6(2002)$ to $5.7(1999) \mathrm{ft}$ \\
Mean irrigation-induced fluctuation & $4.8 \mathrm{ft}$ \\
\hline Maximum total measured fluctuation & $8.2 \mathrm{ft}$ \\
Maximum ground-water level & March 2004 \\
Minimum ground-water level & January 2003 \\
\hline${ }^{1}$ Difference between seasonal low and irrigation-induced peak ground-water level.
\end{tabular}

\section{Timing of Seasonal Peak Levels}

Figures 6 and 7 illustrate the need for careful consideration of the timing of groundwater-level measurements in determining design ground-water levels used in landslideand slope-stability evaluation. Between 1999 and 2004, natural seasonal peak ground- 
water levels occurred within a three month period (March through May) in the lower part of the Sunset Drive landslide (figure 6). In the upper part of the landslide, where landscape irrigation causes a summertime rise in the shallow ground-water table, peak seasonal ground-water levels occurred either in late summer (August and September) or late winter/spring (March or May) (figure 7). The timing of the peak level in the upper part of the landslide is likely a function of the ratio of infiltration of the late winter snowpack to that of landscape irrigation in the summer. The dominance of a late summer timing for the peak level suggests that infiltration of excess landscape irrigation water had a greater impact on ground-water levels than did the snowmelt in the dry years of 1999 through 2003.

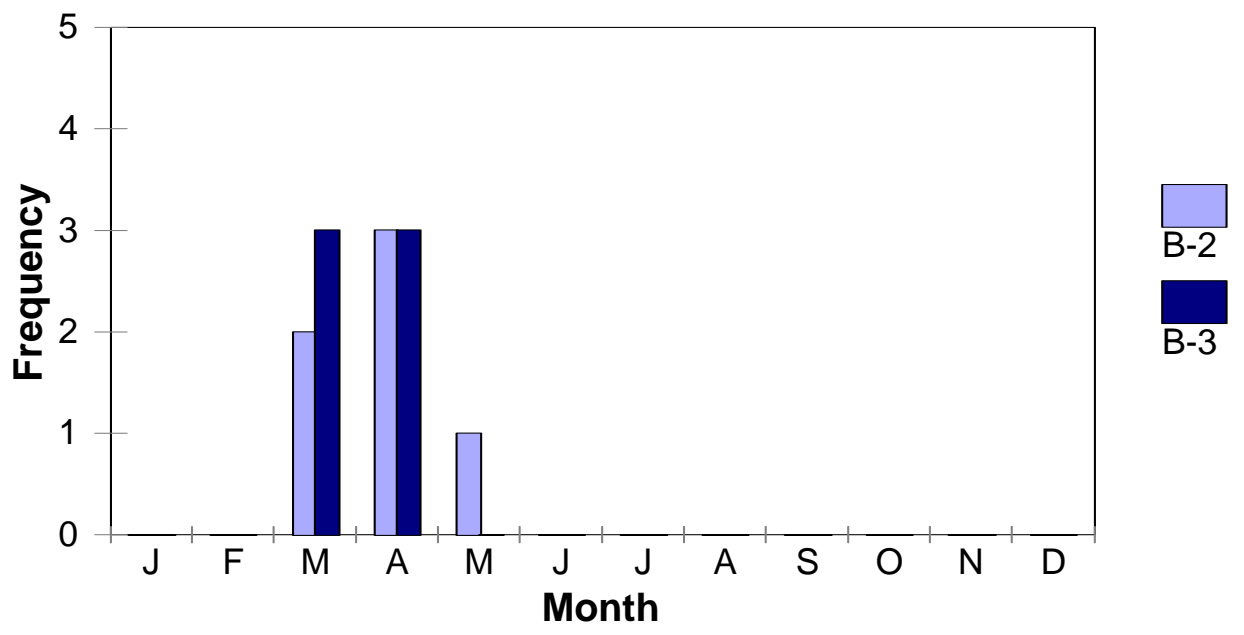

Figure 6. Histogram showing timing of natural peak seasonal ground-water levels in the lower part of the Sunset Drive landslide, Layton between 1999 and 2004. Wells B-2 and B-3 of Terracon Consultants, Inc. (1998). 


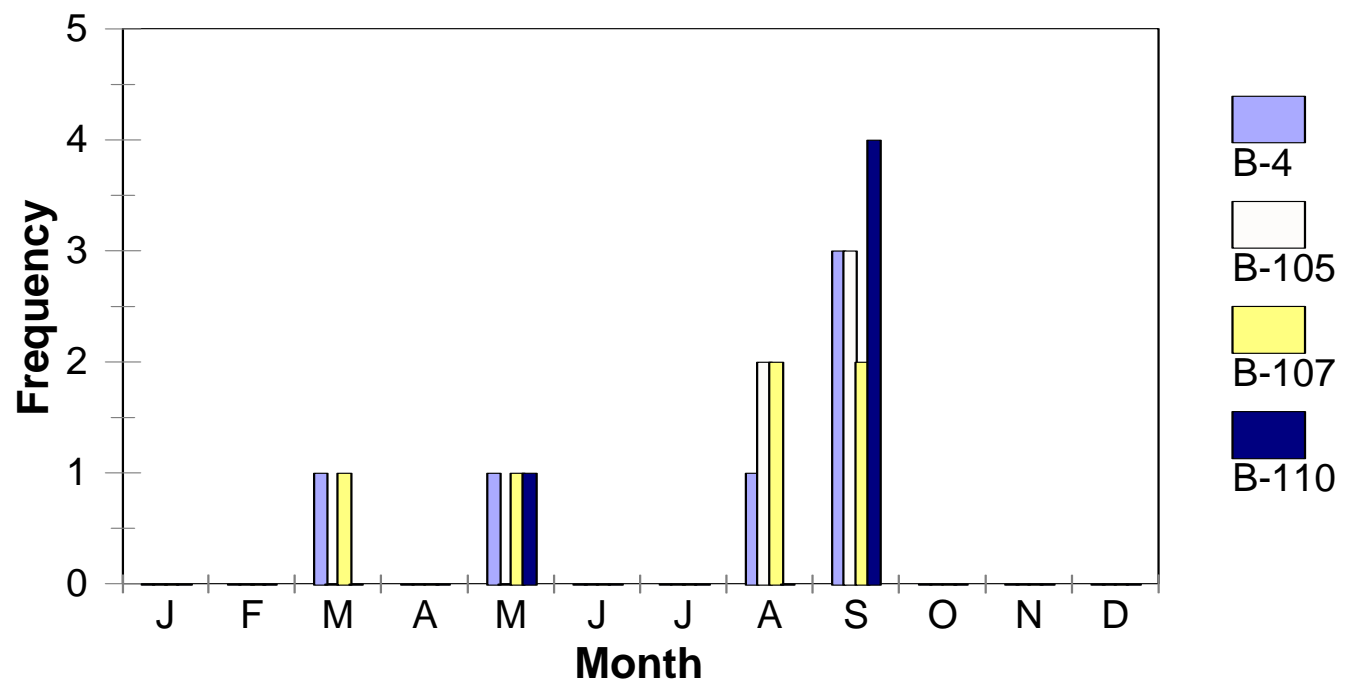

Figure 7. Histogram showing timing of peak seasonal ground-water levels in the upper part of the Sunset Drive landslide, Layton between 1999 and 2004. Well B-4 of Terracon Consultants, Inc. (1998) and B-105 through B-110 of Terracon (1998b). Peak groundwater level omitted where data are incomplete (monthly measurements missing; well B105 in 2004 and well B-110 in 2002).

\section{Intermediate-Term Fluctuations}

Over an intermediate term (periods of roughly a year or more in length), groundwater levels generally declined during the drier than normal years between 1999 and 2003. Subsequently however, at the Sunset Drive landslide, a rise in ground-water levels occurred in 2004 in response to a return to wetter conditions.

Figures 8 and 9 show April ground-water levels since 1999 in two wells at the Sunset Drive landslide in Layton. Both plots show a general decline in the April ground-water levels between 1999 and 2003 and rapid rebound in the level in 2004 following a low in 2003, suggesting the response of levels to the return to wet conditions is faster than the response of dry conditions. 


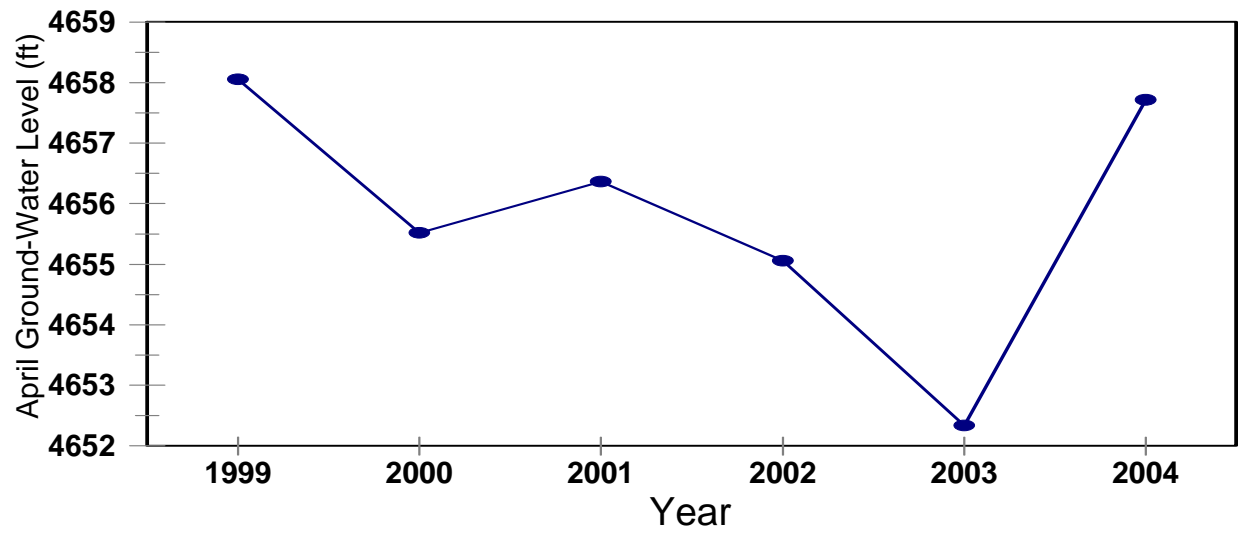

Figure 8. April ground-water level in the lower part of the Sunset Drive landslide, Layton between 1999 and 2004. Well B-3.

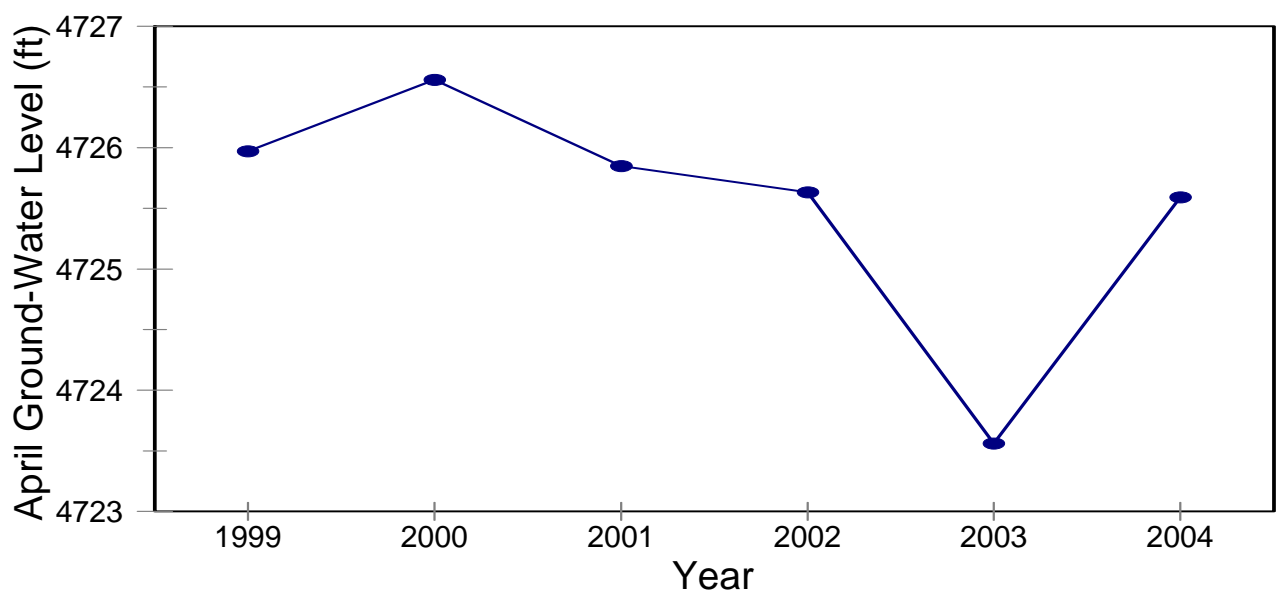

Figure 9. April ground-water level in the crown of the Sunset Drive landslide, Layton between 1999 and 2004. Well B-105.

Figure 10 shows the decline in peak ground-water level in the upper part of the Springhill landslide in North Salt Lake. In all but one year (2000), peak ground-water level in well P-1 occurred in late summer or fall subsequent to summertime landscape irrigation. Well P-1 is in a cul-de-sac surrounded by residential lots and of the six wells 
in the landslide is the only well where the peak ground-water level does not typically occur during the late winter or spring, coincident with snowmelt recharge.

Figure 11 shows the decline in ground-water level in the active (upper) part of the Sherwood Hills landslide complex in Provo between March 2000 and March 2002. The total decline during this period is about 7 feet. A measurement in early 2004 (not plotted) (Terracon, 2004) indicated a ground-water depth of about 24 feet suggesting a total decline of about 14 feet since March 2000.

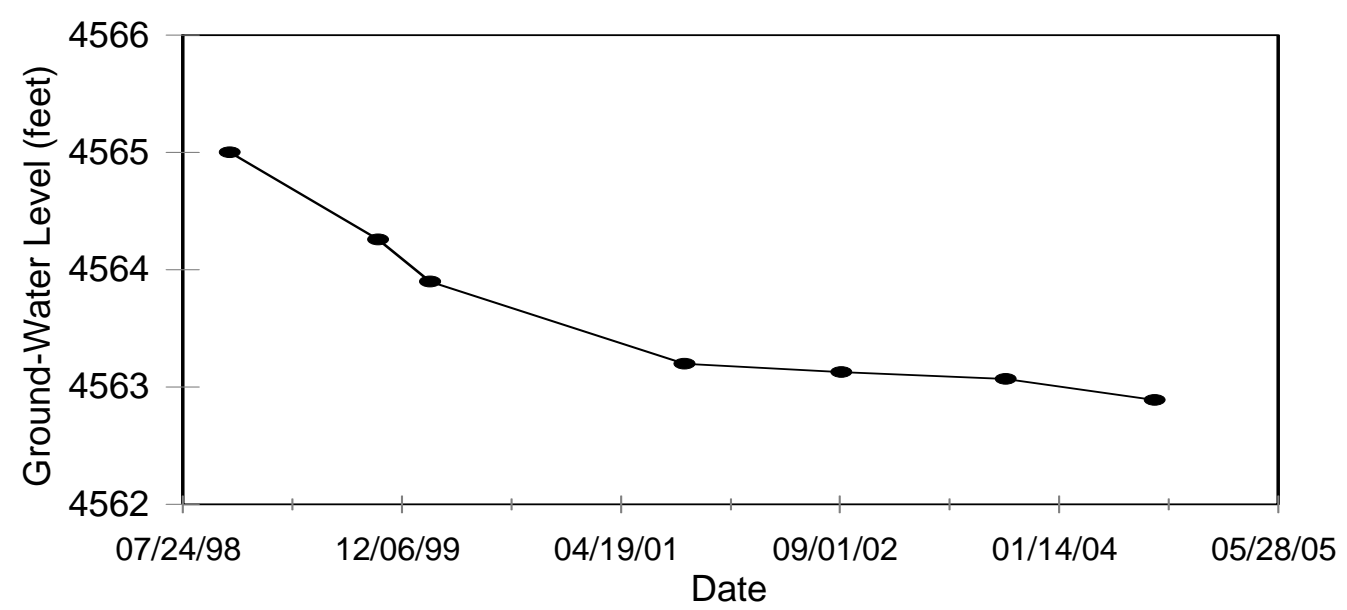

Figure 10. Decline in peak ground-water level in the upper part of the Springhill landslide, North Salt Lake, between 1998 and 2004. Total decline was about 2.1 feet in well P-1 (Terracon, 1998a). Yearly peak ground-water levels occurred in February (2000), August (2004), September (2000-2002), and possibly in November (1998). Ground-water-level data are lacking for most of 1998. 


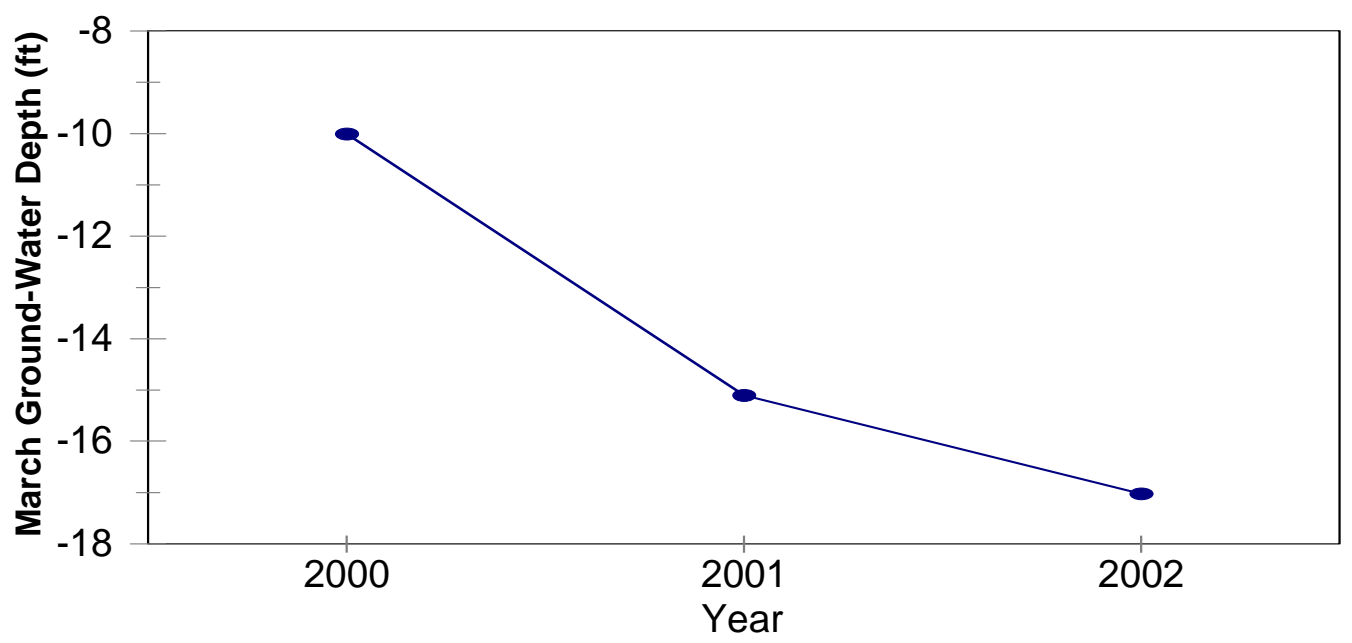

Figure 11. Decline in March ground-water level in the active part of the Sherwood Hills landslide complex, Provo, between 2000 and 2002. Total decline in ground-water level in well SH-1 was about 7 feet. Well SH-1 is in upper main body of landslide and in the central part of the active area of the slide.

\section{Magnitude of Seasonal and Intermediate-Term Fluctuations}

Our measurements provide preliminary information on the magnitude of seasonal and intermediate-term fluctuations in ground-water levels in several Wasatch Front landslides (table 3). Intermediate-term fluctuations in ground-water levels for a select month also reveal the role of deficit precipitation conditions during successive dry years (1999-2003) and the rapidity of peak ground-water-level rise in a single wet year (2004).

\section{Sunset Drive Landslide, Layton}

Measured fluctuations in ground-water levels in a single calendar year at the Sunset Drive landslide range from 1.4 to 8.3 feet. The total measured fluctuations since April 1999 (the difference between the lowest and highest measured values) range between 5.2 and 8.8 feet. Given the measurement period only spans six years, we infer they are minimum fluctuations at each well and believe larger fluctuations are possible. 
Table 3. Seasonal and measured total fluctuations (MTF) in ground-water levels, Sunset Drive landslide, between 1999 and 2004.

\begin{tabular}{|l|cccccc|c|}
\hline Well & Seasonal & Fluctuation & In & Ground- & Water & Level & $\begin{array}{c}\text { MTF } \\
\text { (ft) }\end{array}$ \\
\hline Year & $\mathbf{1 9 9 9}$ & $\mathbf{2 0 0 0}$ & $\mathbf{2 0 0 1}$ & $\mathbf{2 0 0 2}$ & $\mathbf{2 0 0 3}$ & $\mathbf{2 0 0 4}$ & \\
\hline B-2 & 5.5 & 2.8 & 2.2 & 2.7 & 1.4 & 6.4 & 6.6 \\
B-3 & $\mathbf{6 . 4}$ & 4.5 & $\mathbf{5 . 7}$ & $\mathbf{5 . 1}$ & 2.2 & $\mathbf{8 . 3}$ & $\mathbf{8 . 8}$ \\
B-4 & 3.3 & 4.1 & 2.9 & 2.0 & 3.0 & 7.0 & 7.0 \\
B-105 & 5.0 & 4.9 & 4.2 & 3.5 & 3.7 & $5.5^{1}$ & 6.5 \\
B-107 & 5.9 & $\mathbf{5 . 4}$ & 4.8 & 3.6 & $\mathbf{4 . 5}$ & 7.7 & 8.2 \\
B-110 & 3.1 & 3.8 & 2.8 & 1.4 & 2.5 & 4.9 & 5.2 \\
\hline Mean & 4.9 & 4.3 & 3.8 & 3.1 & 2.9 & 6.6 & 7.1 \\
\hline
\end{tabular}

${ }^{1}$ Missing monthly measurements in 2004 may include peak level.

Bold indicates maximum fluctuation in year or measurement period.

Well B-3 in lower main body of landslide, well B-2 in upper slide, well B-4 in head of slide, and wells B-105 through 110 in crown of slide.

Abbreviation: MTF - measured total fluctuation (for period)

\section{Springhill Landslide, North Salt Lake}

Measured seasonal fluctuations in ground-water levels in a single calendar year at the Springhill landslide range from 0.5 to 3.0 feet (table 4), excluding changes in groundwater level in two wells likely affected by dewatering during excavation of a nearby sewer line. The total measured fluctuations since August 1998 (the difference between the lowest and highest measured values) range between 2.3 and 4.5 feet excluding data from the two wells referred to above.

Table 4. Seasonal and measured total fluctuations (MTF) in ground-water levels, Springhill landslide, North Salt Lake, between 1999 and 2004.

\begin{tabular}{|l|cccccc|c|}
\hline Well & Seasonal & Fluctuation & in & Ground- & Water & Level & $\begin{array}{c}\text { MTF } \\
\text { (ft) }\end{array}$ \\
Year & $\mathbf{1 9 9 9}$ & $\mathbf{2 0 0 0}$ & $\mathbf{2 0 0 1}$ & $\mathbf{2 0 0 2}$ & $\mathbf{2 0 0 3}$ & $\mathbf{2 0 0 4}$ & \\
\hline P-1 & 1.2 & 0.9 & 0.9 & 1.0 & 0.9 & $\mathbf{1 . 0}$ & 3.1 \\
P-2 & $4.0^{1}$ & 0.7 & 0.6 & 1.0 & 0.4 & 0.5 & $4.0^{1}$ \\
P-3 & 2.0 & 0.8 & 1.7 & 1.6 & 0.7 & 0.5 & 2.3 \\
P-4 & 2.6 & $\mathbf{2 . 1}$ & 1.4 & 1.5 & 1.0 & 0.7 & 4.5 \\
P-6 & $\mathbf{7 . 1}$ & 1.1 & $\mathbf{3 . 0}$ & $\mathbf{1 . 7}$ & $\mathbf{1 . 4}$ & -- & $\mathbf{7 . 1}$ \\
\hline Mean & $1.9^{2}$ & 1.1 & 1.5 & 1.4 & 0.9 & 0.7 & $3.3^{2}$ \\
\hline
\end{tabular}

${ }^{1}$ Sewer line excavation likely lowered ground-water levels in well.

${ }^{2}$ Excludes fluctuations affected by sewer line excavation.

Bold indicates maximum fluctuation in year or measurement period.

Well P-1 in upper landslide. Wells P-2 through P-6 in main body of landslide.

Abbreviation: MTF - measured total fluctuation (for period). 
The smaller ground-water-level fluctuations at the Springhill landslide than at the Sunset Drive landslide suggest the combination of factors that control ground-water levels differs between the two sites. These factors include late-winter snowpack, subsurface geology, topography, hillside modifications, and proximity to the Wasatch fault zone. Late-winter snowpack is typically greater at the Springhill landslide than at the Sunset Drive landslide; however, other factors that influence snowmelt recharge, such as near-surface soil type, ground cover, lot slope, and presence of shallow permeable fill are more likely to promote infiltration at the Sunset Drive landslide. Near-surface clay soils at the Springhill landslide may promote runoff of snowmelt water rather than infiltration. Whereas most of the Sunset Drive landslide is covered by native slope or back-lot lawns, a large part of the Springhill landslide is covered by impermeable roads, sidewalks, driveways, and houses. Although overall lot slope may be similar at each landslide, flatter areas at the Springhill landslide are largely paved and many of the lawn or native areas are moderately sloping. Borehole logs (Terracon Consultants, Inc., 1998) show up to 12.5 feet of fill in the crown of the Sunset Drive landslide. In one borehole (B-4), the base of the fill soil consists of permeable, poorly graded (well sorted) sand.

Ground water in the Springhill landslide is likely partly controlled by a more complex hydrogeologic system than in the Sunset Drive landslide. The Springhill area was formerly a sand and gravel pit and an unknown amount of excavation preceded development of the residential subdivision. Excavation likely stopped when weathered Tertiary rock and clay was encountered in the pit. Springs and seeps in the area are likely due to the intersection of a deep, fracture-controlled ground-water system with the present ground surface. Ground-water depths differ by more than 9 feet in two separate pairs of wells in the same road where each pair of wells is separated by only about 3 feet in elevation, suggesting that ground-water may be hydraulically isolated, flowing along separate transmissive zones in the landslide.

\section{Millbrook Way Landslide, Bountiful}

Measured seasonal fluctuations in ground-water levels in a single calendar year at the Millbrook Way landslide range from 1.2 to 5.7 feet (table 5), but actual ground-waterlevel fluctuations are greater because ground-water levels drop below the bottom of shallow wells in the slide during the summer and fall. Figure 12 shows the natural seasonal fluctuation in ground-water level in a well in the head of the landslide that is characterized by a snowmelt-induced rise in late winter and spring. Undeveloped land exists directly upslope of the landslide. 
Table 5. Seasonal fluctuations in ground-water levels, Millbrook Way landslide, Bountiful, between 2002 and 2004.

\begin{tabular}{|c|c|c|c|}
\hline Well & $\begin{array}{l}\text { Seasonal } \\
\text { Ground- }\end{array}$ & $\begin{array}{l}\text { Fluctuation }{ }^{1} \\
\text { Water }\end{array}$ & $\begin{array}{l}\text { in } \\
\text { Levels }\end{array}$ \\
\hline Year & 2002 & 2003 & 2004 \\
\hline W-1 & 4.5 & 3.4 & 5.2 \\
\hline W-2 & 1.2 & --- & --- \\
\hline W-3 & 5.7 & 3.9 & 5.5 \\
\hline W-4 & --- & 1.2 & 3.1 \\
\hline Mean & 3.8 & 2.8 & 4.6 \\
\hline
\end{tabular}

${ }^{1}$ Minimum fluctuations because ground-water levels drop below bottom of shallow wells.

Bold indicates maximum fluctuation in year or measurement period.

Wells $\mathrm{W}-1$ and $\mathrm{W}-3$ at base of main scarp of landslide. Wells B-2 and B-4 in crown of landslide.

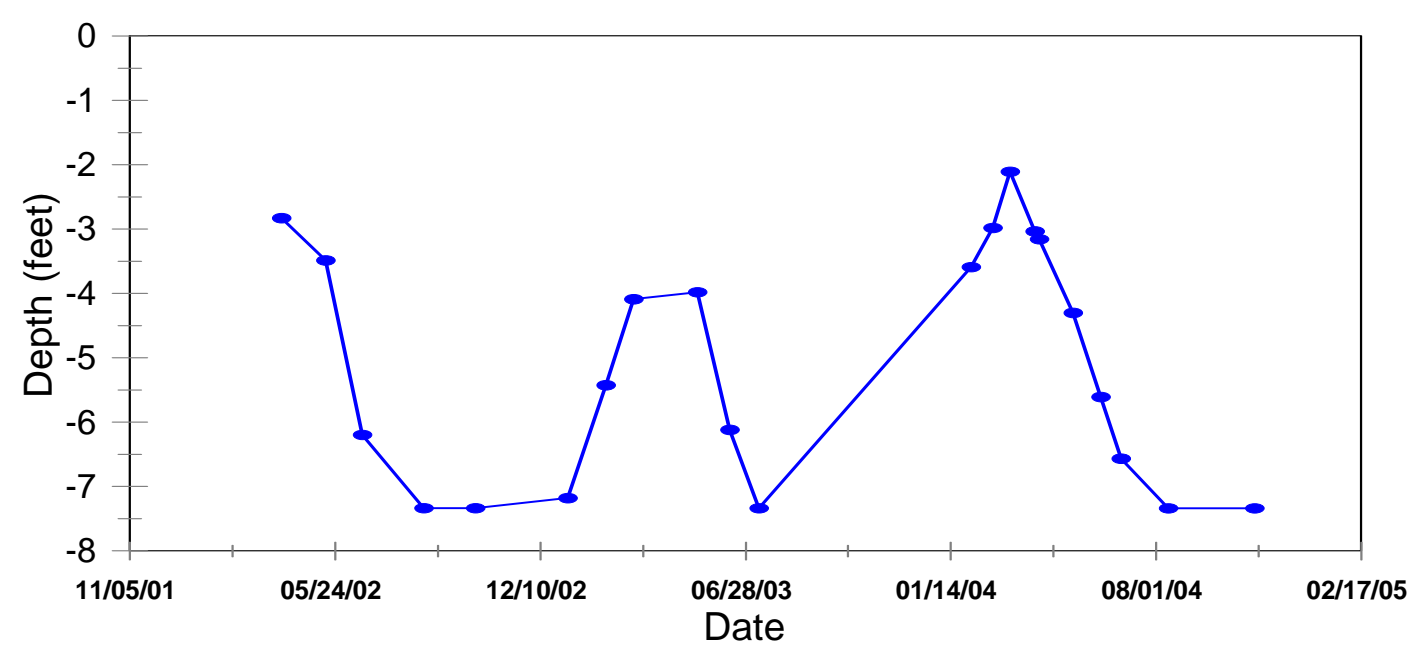

Figure 12. Natural seasonal fluctuation in ground-water level in the head of the Millbrook Way landslide, Bountiful. Well W-1 at base of main scarp.

\section{RELATION BETWEEN GROUND-WATER LEVELS AND PRECIPITATION}

Previous landslide researchers (Godfrey, 1985; Fleming and Schuster, 1985; Ashland, 2003) inferred that ground-water levels in landslides fluctuated in response to cumulative excess or deficit precipitation. Ashland (2003, figure 4) also showed that individual rainstorm events can cause a transient rise in ground-water level in a landslide. This study documents a relation between both monthly and annual precipitation on groundwater levels in landslides. 


\section{Monthly Precipitation}

Figure 13 shows the relation between ground-water level in well B-105, in the crown of the Sunset Drive landslide, and monthly precipitation from April 1999 to September 2002. The plots show that a natural rise in ground-water level overlaps with the wet months of March through May, a period that also generally coincides with snowmelt recharge at lower elevations. In three of the four years (2000-2002), the rise in groundwater level initiated in February, suggesting it was triggered by late-winter snowmelt. In two of the four years (2000 and 2002), the natural peak ground-water level immediately followed (appears to coincide in figure 13) the wettest month in the first half of the year. In all four years, which were drier than normal, peak seasonal ground-water level occurred in August or September near the end of the landscape-irrigation season. The onset of the rise in ground-water level to peak level occurred during periods of declining precipitation, except in 2001. In some years (2000 and 2001), wet summer months contributed to a rise in ground-water levels.

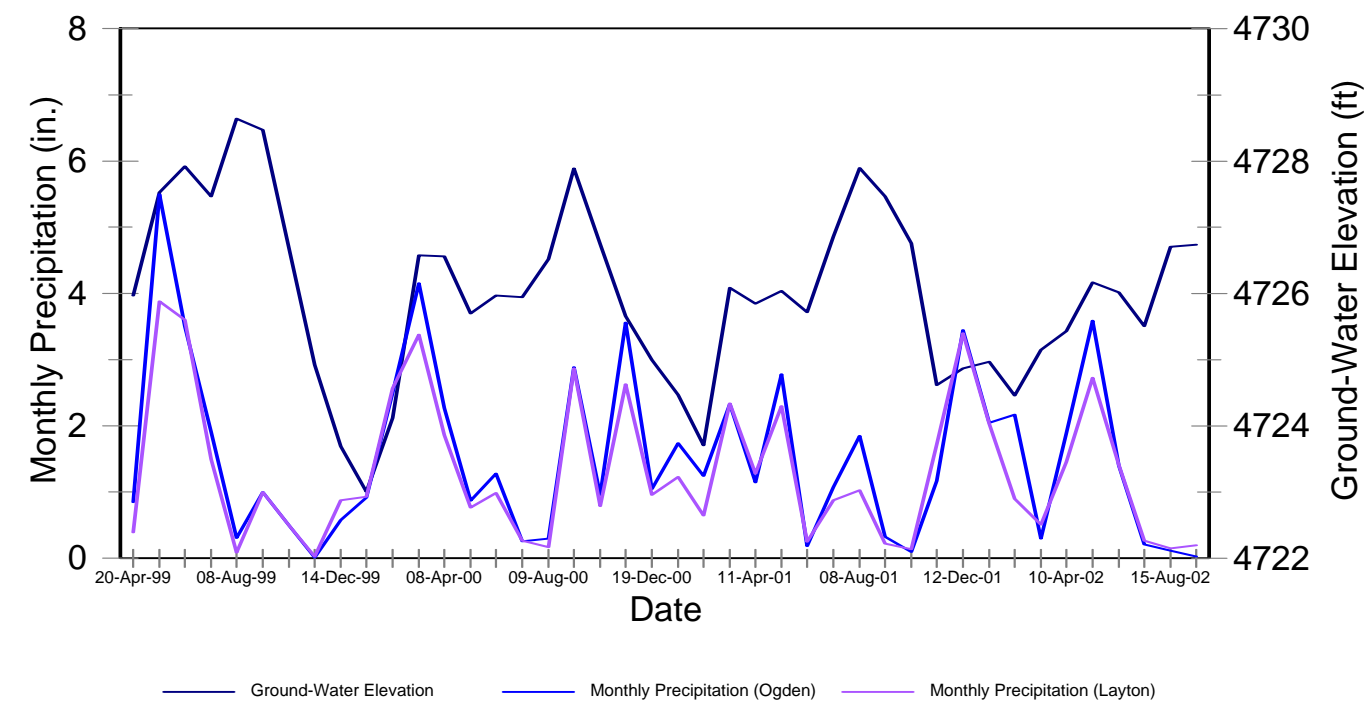

Figure 13. Relation between ground-water level and monthly precipitation in crown of Sunset Drive landslide, Layton. Well B-105. Ground-water-level measurement plotted with precipitation totals for previous month.

\section{Annual Precipitation}

Intermediate-term ground-water levels in landslides fluctuate in response to the cumulative excess or deficit precipitation that occurs in a year. Ashland (2003) used a modified water year, the landslide water year (LWY) that begins September 1 and ends August 30, to track cumulative excess/deficit precipitation as a means of indirectly estimating ground-water level. Figure 13 shows the relation between annual (LWY) precipitation and ground-water level in the lower Sunset Drive landslide. The groundwater level measurement immediately follows the end of the LWY in figure 14. The 
1998-99 and 2003-04 LWYs were wetter than normal (using a UGS estimate of normal annual precipitation for Layton which currently lacks a calculated 30-year normal annual precipitation value from the National Weather Service). The highest ground-water level for the measurement period followed the 1998-99 LWY and a rise in ground-water level followed the 2003-04 LWY. Ground-water level declined during the intervening drierthan-normal LWYs. The total decline in ground-water level during the dry years was about 1.3 feet, but ground-water level rose nearly a half foot following the first wetterthan-normal LWY (2003-04).

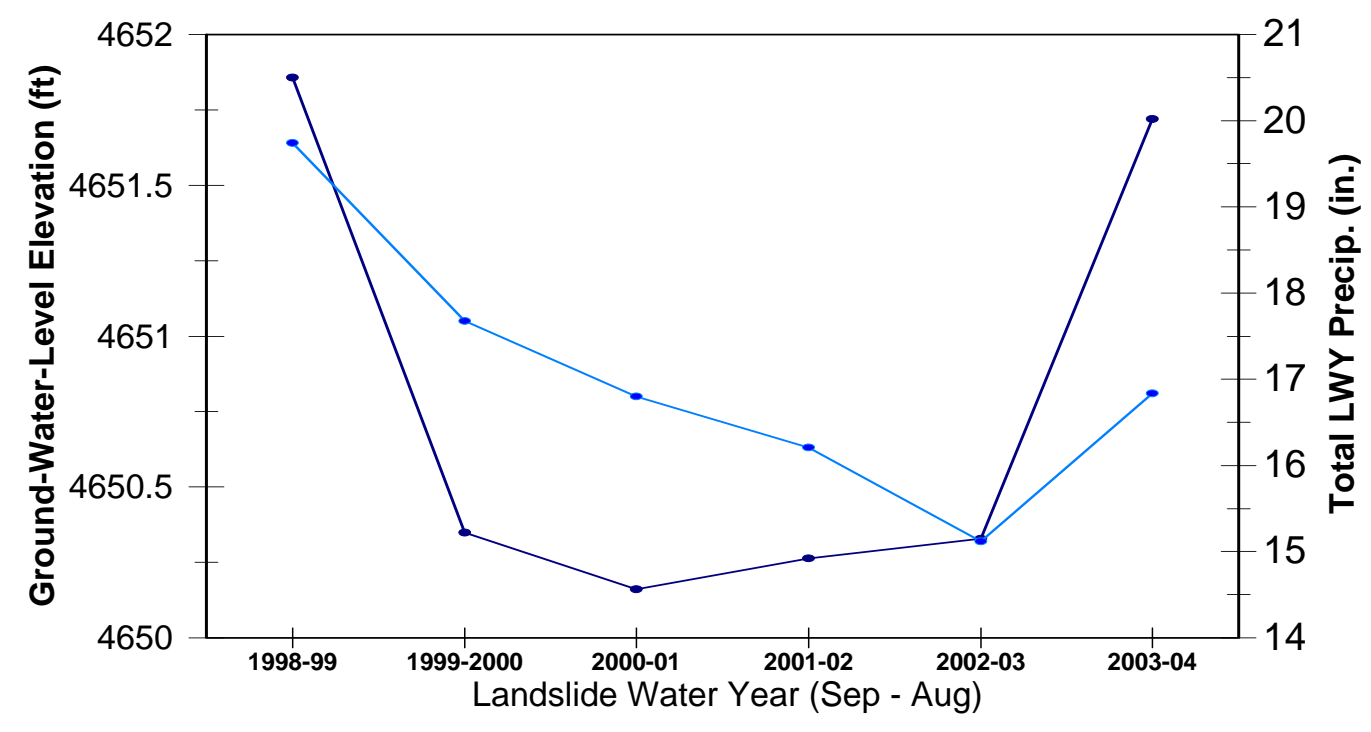

- LWY Precipitation - - September GWL

Figure 14. Relation between ground-water level and annual precipitation in lower Sunset Drive landslide. September ground-water level $(G W L)$ in well B-3 versus total precipitation in previous landslide water year (LWY).

\section{CONCLUSIONS}

Our data document seasonal and intermediate-term ground-water-level fluctuations that can be used to estimate design ground-water levels in landslide- and slope-stability analyses. The data span a relative drought period (1999-2003), but locally document the effects of wetter than normal precipitation on ground-water levels in 2004. Based on nearby ground-water-level data from unconsolidated surficial deposits (Burden and others, 2000), our initial ground-water-level measurements likely directly followed historically high levels in the late 1990s that coincided with active landsliding (Ashland, 2003).

Seasonal ground-water levels fluctuate in response to both late winter/early spring snowmelt (natural seasonal fluctuation) and locally to summertime landscape irrigation 
(lawn watering) (irrigation-induced fluctuation). We measured seasonal ground-waterlevel fluctuations up to a maximum of 8.3 feet, with mean fluctuations ranging from about 0.7 to 6.6 feet at three of the landslides. More variability exists in the natural seasonal peak ground-water levels than in the seasonal low levels in a single well. The timing of seasonal peak ground-water levels varies depending on the contribution of the infiltration of landscape irrigation water (lawn watering) on ground-water levels. Natural seasonal peak ground-water levels typically occur in late winter/early spring (March through May), whereas irrigation-induced peak seasonal ground-water levels mostly occur in later summer.

Our data quantifies, in a preliminary manner, intermediate-term fluctuations in ground-water levels in landslides, but more data are needed over a longer period. The measured total fluctuation at the Sunset Drive (Layton) and Springhill (North Salt Lake) landslides ranged from 5.2 to 8.8 feet and from 3.1 to 4.5 feet, respectively. A decline in ground-water level of 14 feet occurred in a well in the upper part of the Sherwood Hills landslide complex, between 2000 and 2004. Measurements of same-month and/or peak levels showed that ground-water levels generally declined over the drought period (19992003), but locally rose in response to wetter than normal conditions in 2004. Preliminary data suggest the rebound in ground-water levels in wet periods is more rapid than the decline during dry periods.

\section{LIMITATIONS}

Some conclusions in this report are based on data presented in geologic and geotechnical reports prepared by others. The Department of Natural Resources, Utah Geological Survey (UGS), provides no warranty that the data in these reports are correct and accurate.

In general, a lack of information on borehole logs indicating soil moisture, initial ground-water levels, and well construction made it difficult to interpret ground-water conditions (confined, unconfined, or perched). Sample-specific soil-moisture information is typically lacking in consultant's reports. Ground-water conditions can best be inferred only where soil-moisture information (dry, moist, wet, saturated) for each sample is combined with the depth to the top of a saturated layer (initial ground-water level). Well construction may influence ground-water levels, particularly where levels are near the bottom of the monitoring well (water trapped below the lowest slot in the well screen, particularly where a commercial well screen is not used), or surface water enters the borehole (no cement or bentonite seal or where the seal is improperly located in road box forcing runoff water into well). In general, the observed ground-water-level fluctuations suggest that well construction did not have any significant influence on ground-water level. Where a significant influence was suspected, the data were not used in this report. 


\section{REFERENCES}

Ashland, F.X., 2003, Characteristics, causes, and implications of the 1998 Wasatch Front landslides: Utah Geological Survey Special Study 105, 49 p.

Burden, C.B., and others, 2000, Ground-water conditions in Utah, spring of 2000: Utah Division of Water Resources Cooperative Investigations Report Number 41, 140 p.

Fleming, R.W., and Schuster, R.L., 1985, Implications of the current wet cycle to landslides in Utah, in Bowles, D.S., editor, Delineation of landslide, flood, and debris flow hazards in Utah: Logan, Utah, Utah Water Research Laboratory, Utah State University, p. 19-28.

Godfrey, A.E., 1985, Utah's landslides of 1983 as a magnitude-frequency event with a finite return probability, in Bowles, D.S., editor, Delineation of landslide, flood, and debris flow hazards in Utah: Logan, Utah, Utah Water Research Laboratory, Utah State University, p. 67-85.

Hayes, Toby, 2003, Utahns overwatering lawns: Salt Lake City, Deseret News, July 7, 2003.

Kaliser, B.N., and Slosson, J.E., 1988, Geologic consequences of the 1983 wet year in Utah: Utah Geological and Mineral Survey Miscellaneous Publication 88-3, 109 p.

Terracon Consultants, Inc., 1998, Geotechnical report, Sunset Drive landslide, Layton, Utah: Salt Lake City, unpublished consultant's report, 11 p.

Terracon, 1998a, Geotechnical report, Springhill landslide, City of North Salt Lake, Utah: Salt Lake City, unpublished consultant's report, 23 p.

-----1998b, Interceptor trench borings, Sunset Drive landslide, Layton, Utah: Salt Lake City, unpublished consultant's report, 2 p.

-----1999, Inclinometer and piezometer readings, Sunset Drive landslide, Layton, Utah: Salt Lake City, unpublished consultant’s report, 2 p.

-----2000, Inclinometer and piezometer readings, Springhill subdivision, North Salt Lake, Utah: Salt Lake City, unpublished consultant's report, 2 p.

-----2001, Report of phase II initial geotechnical engineering evaluations, Sherwood Hills, subdivision-wide studies, Provo, Utah: Salt Lake City, unpublished consultant's report, $44 \mathrm{p}$.

-----2002, Report of additional studies for phase II - initial geotechnical engineering evaluation, Sherwood Hills subdivision-wide studies, Provo, Utah: Salt Lake City, unpublished consultant's report, $17 \mathrm{p}$. 
-----2004, Inclinometer update, Sherwood Hills subdivision-wide studies: Salt Lake City, unpublished consultant's report, 3 p.

URS/Dames \& Moore, 2001, Phase I geologic evaluation and Phase V geological hazards map update, Sherwood Hills subdivision-wide studies and update of Provo City geologic hazard maps: Salt Lake City, Utah, unpublished consultant’s report, 33 p. 